\title{
The Efficiency of Arabidopsis thaliana Floral Dip Transformation Is Determined Not Only by the Agrobacterium Strain Used but Also by the Physiology and the Ecotype of the Dipped Plant
}

\author{
Rim Ghedira, Sylvie De Buck, Jonah Nolf, and Ann Depicker \\ Department of Plant Systems Biology, VIB and Department of Plant Biotechnology and Bioinformatics, Ghent University, \\ 9052 Gent, Belgium
}

Submitted 19 November 2012. Accepted 29 March 2013.

\begin{abstract}
To evaluate the chromosomal background of different Agrobacterium strains on floral dip transformation frequency, eight wild-type Agrobacterium strains, provided by Laboratorium voor Microbiologie Gent (LMG) and classified in different genomic groups, were compared with the commonly used Agrobacterium strains C58C1 Rif (pMP90) and LBA4404 in Arabidopsis thaliana Columbia (Col-0) and C24 ecotypes. The C58C1 Rif ${ }^{r}$ chromosomal background in combination with the pMP90 virulence plasmid showed high Col-0 floral dip transformation frequencies (0.76 to 1.57\%). LMG201, which is genetically close to the Agrobacterium C58 strain, with the same virulence plasmid showed comparable or even higher transformation frequencies (1.22 to $\mathbf{2 . 2 8 \%}$ ), whereas the LBA4404 strain displayed reproducibly lower transformation frequencies $(<0.2 \%)$. All other tested LMG Agrobacterium chromosomal backgrounds had transformation frequencies between those of the C58C1 Rif (pMP90) and LBA4404 reference strains. None of the strains could transform the $\mathrm{C} 24$ ecotype with a frequency higher than 0.1\%. Strikingly, all Arabidopsis Col-0 floral dip transformation experiments showed a high transformation variability from plant to plant (even more than 50-fold) within and across the performed biological repeats for all analyzed Agrobacterium strains. Therefore, the physiology of the plant and, probably, the availability of competent flowers to be transformed determine, to a large extent, floral dip transformation frequencies.
\end{abstract}

Members of Agrobacterium, a genus of gram-negative, aerobic, rod-shaped bacteria found in soil (Kersters and De Ley 1984), can invade roots and stems of plants via wounds, triggering the transformation of plant cells into proliferating tumor cells called crown galls (Aloni and Ullrich 2008; Binns 2008; Dafny-Yelin et al. 2008; Tzfira and Citovsky 2000; Tzfira et al. 2004). On the molecular level, Agrobacteriummediated plant infection results from the transfer of a bacterial

R. Ghedira and S. De Buck contributed equally to this article.

Corresponding author: A. Depicker; Telephone: +32.9.331.39.40; Fax: +32.9.331.38.09; E-mail: ann.depicker@psb.vib-ugent.be

* The $\boldsymbol{e}$-Xtra logo stands for "electronic extra" and indicates that one supplementary figure is published online.

(C) 2013 The American Phytopathological Society
DNA fragment, the so-called T-DNA, to the plant cell nucleus, in which it integrates into the plant chromosomal DNA and becomes expressed (Dafny-Yelin et al. 2008; Gelvin 2010, 2012; McCullen and Binns 2006; Tzfira and Citovsky 2006). Three genetic elements are necessary for the transfer and integration of T-DNA in the plant genome: the border repeats that delimit the T-DNA, the vir genes that encode the in transacting type IV secretion system, and various bacterial chromosomal genes that are necessary for attachment and early stages of transformation (Gelvin 2010; Pitzschke and Hirt 2010). Genes involved in attachment are located on the Agrobacterium chromosome, and mutants in these loci $(\operatorname{chv} A, \operatorname{chvB}$, and $p \operatorname{cs} A$, or exoC) are avirulent to many plant species because they cannot infect plants (Leigh and Coplin 1992; Thomashow et al. 1987; Zorreguieta et al. 1988).

The genome of Agrobacterium tumefaciens C58 has four distinct replicons: a circular chromosome, a linear chromosome, and plasmids pAtC58 and pTiC58 (Goodner et al. 2001; Slater et al. 2008; Wood et al. 2001). The att genes are located on the pAtC58 plasmid of the bacterium (Goodner et al. 2001), but this plasmid seems not essential for virulence when the pTiC58 plasmid is present (Nair et al. 2003). However, both plasmids are required for maximal virulence. By growing Agrobacterium strain $\mathrm{C} 58$ at $37^{\circ} \mathrm{C}$, the cured non-tumor inducing strain $\mathrm{C} 58 \mathrm{C} 1$ was generated, due to the loss of its pTiC58 plasmid (Van Larebeke et al. 1974). The C58C1 rifampicin-resistant $\left(\mathrm{Rif}^{\mathrm{r}}\right)$ streptomycin-resistant $\left(\mathrm{Strep}^{\mathrm{r}}\right)$ strain, also called GV3101, was obtained by plating the C58C1 strain on selective medium containing both Rif and Strep (Van Larebeke et al. 1974). Strain C58C1 Rif ${ }^{\mathrm{r}}$ (pMP90), which is now commonly used for the production of transgenic plants, was obtained by introducing the vir plasmid pMP90, which is derived from the T37 strain's Ti plasmid, very closely related to pTiC58 (Depicker et al. 1980) but in which the complete TDNA region was substituted by a gentamycin resistance gene (Koncz and Schell 1986). Strain LBA4404 has an Ach5 chromosomal background and a vir plasmid derived from pTiAch5 by deletion of the T-DNA region (Hoekema et al. 1983).

Using Agrobacterium spp., two main methods can be employed for Arabidopsis transformation: in vitro, tissue culturedependent methods such as root and leaf explant transformation (Valvekens et al. 1988) and in planta methods such as vacuum infiltration and floral dip transformation (Bechtold et al. 1993; Clough and Bent 1998). The floral dip transformation method is currently most often used because of the easy, cheap, and quick protocol. Nevertheless, not all Arabidopsis 
ecotypes can be transformed as efficiently with both transformation methods. By root transformation, Arabidopsis ecotypes C24 and Wassilewskija (Ws) are efficiently transformed, while Landsberg erecta (Ler) and Columbia (Col-0) are less efficiently transformed (Valvekens et al. 1988; unpublished results). On the other hand, Col-0 is efficiently transformed by floral dip, while the Arabidopsis Ler ecotype is transformed at rates 10- to 100-fold lower (Clough and Bent 1998). On the bacterial side, the density of the bacterial culture, the ability to attach and transfer its T-DNA to the host cells, and the origin of the Ti plasmids influence in vitro transformation frequency (Cheng et al. 2004; Dillen et al. 1997; Melchers et al. 1990; Nam et al. 1997; Opabode 2006; Shen et al. 1993), while no influence of the bacterial density was noted on floral dip transformation efficiencies (Clough and Bent 1998). For the Arabidopsis Ws ecotype, shoot regeneration was most efficient when using strain EHA101 as compared with the C58C1 Rif ${ }^{\mathrm{r}}$ (pTiR225) and LBA4404 strains (Akama et al. 1992), whereas in vitro transformation of the Arabidopsis Ler ecotype was more effective with the C58C1 Rif ${ }^{\mathrm{r}}$ (pTiR225) strain than with the EHA101 strain (Akama et al. 1992).

The goal of this study was to identify an Agrobacterium strain with higher transformation frequencies after Arabidopsis thaliana floral dip transformation than the currently used Agrobacterium strains C58C1 Rif ${ }^{\mathrm{r}}$ (pMP90) and LBA4404. Therefore, eight different wild-type Laboratorium voor Microbiologie Gent (LMG) Agrobacterium strains, selected from five different genetic groups in the Belgian Co-ordinated Collections of Micro-organisms database (BCCM), were used for floral dip transformation of Arabidopsis thaliana ecotypes Col-0 and C24. Their floral dip transformation efficiencies were compared with those of the widely used LBA4404 strain and three variant strains based on the $\mathrm{C} 58 \mathrm{C} 1$ chromosomal background. The most effective Agrobacterium strains (LMG62 and LMG201) were further analyzed in floral dip cotransformation experiments with the commonly used Agrobacterium strains C58C1 Rif ${ }^{\mathrm{r}}$ (pMP90), EHA101, AGL1, and LBA4404 to determine their relative transformation efficiencies within individual seed stocks.

\section{RESULTS}

\section{Experimental setup to test the transformation efficiencies of eight wild-type LMG Agrobacterium strains.}

Eight wild-type LMG Agrobacterium strains were purchased from the BCCM collection (Table 1). These strains have been classified in different groups based on their DNA-DNA renaturation kinetics and, later, in different genomic species via amplification fragment length polymorphism (Costechareyre et al.

Table 1. Classification of the Agrobacterium species used in this study

\begin{tabular}{lcclc}
\hline Number & Group 1 $^{\mathbf{a}}$ & Group 2 $^{\mathbf{b}}$ & \multicolumn{1}{c}{ Name } & Pathogenic $^{\mathbf{c}}$ \\
\hline C58 & TT9 & G8 & A. tumefaciens & + \\
LMG201 & TT9 & G8 & A. tumefaciens & + \\
LMG26 & 362 & G9 & Agrobacterium sp. & + \\
LMG148 & B6 & G4 & A. radiobacter & - \\
LMG62 & B6 & G4 & A. radiobacter & - \\
LMG146 & M2/1 & G2 & A. radiobacter & - \\
LMG147 & M2/1 & G2 & A. radiobacter & - \\
LMG142 & TT111 & G1 & A. radiobacter & - \\
LMG232 & TT111 & G1 & A.tumefaciens & - \\
LBA4404 & TT111 & G1 & A. tumefaciens & - \\
\hline
\end{tabular}

${ }^{a}$ According to De Ley $(1972,1974)$.

b According to Portier and associates (2006) and Costechareyre and associates (2009).

${ }^{c}+$ indicates the wild-type strain is pathogenic; - indicates the wild-type strain is not pathogenic.
2009; De Ley 1972, 1974; Portier et al. 2006). Strains LMG142 and LMG232 belong to the same G1 group as LBA4404, whereas strains LMG201 and C58 are both classified in group G8. The other six wild-type strains are classified in group G2 (LMG146 and LMG147), G4 (LMG148 and LMG62), and G9 (LMG26) (Table 1). From each of these eight LMG strains, a Rif $^{\mathrm{r}}$ mutant was isolated, and the nopaline vir helper plasmid pMP90 and the binary vector pTJK136, with a T-DNA carrying the intron-containing $\beta$-glucuronidase (GUS) reporter gene and the kanamycin resistance gene (Kapila et al. 1997), were introduced. To check the stability of both the vir plasmid and the binary T-DNA vector in the absence of selection, the number of colony-forming units for each Agrobacterium strain were compared after overnight growth on selective (gentamycin for pMP90 or kanamycin for pTJK136) and nonselective yeast extract broth (YEB) medium. The results showed that the binary T-DNA vector was stably replicated in all chromosomal backgrounds and also that the pMP90 vir plasmid was stably maintained in all tested Agrobacterium strains except LMG146 Rif (pMP90, pTJK136), in which the vir plasmid was maintained in only $1 \%$ of the bacteria (data not shown). Due to vir plasmid instability in LMG146 Rif $^{\mathrm{T}}$ (pMP90, pTJK136), we did not include the results of this strain in the analyses.

The floral dip transformation efficiencies of the seven remaining LMG strains were compared with those of the commonly used Agrobacterium strains C58C1 Rif ${ }^{\mathrm{r}}$ (pMP90, pTJK136), harboring a nopaline vir helper plasmid, C58C1 Rif $^{\mathrm{r}}$ (pGV2260, pTJK136), harboring an octopine vir helper plasmid, C58C1 Ecm ${ }^{\mathrm{r}}$ (pMP90, pTJK136), resistant to erythromycin and chloramphenicol, and LBA4404 (pTJK136).

Floral dip transformation of the Arabidopsis Col-0 and C24 (Table 2) ecotypes was performed in two to four biological repeats. In each biological repeat, five individual plants were dipped in the same sequence as they were numbered, using the same Agrobacterium culture. The plants were allowed to set seeds, and the seeds were collected per individual plant. Two thousand Arabidopsis seeds, harvested from each dipped plant, were sown on kanamycin-selective medium, and the number of kanamycin-resistant Arabidopsis plants was scored for all dipped plants.

\section{Arabidopsis thaliana Col-0 floral dip transformation frequencies are highly variable from plant to plant.}

After floral dip transformation of Arabidopsis thaliana plants, ecotype Col-0, the number of transformants for each Agrobacterium strain was highly variable within and across the different experiments performed (Table 2). For instance, with reference strain C58C1 Rif (pMP90, pTJK136) in experiments a, b, c and $\mathrm{d}$, the number of transformants per 2,000 seeds varied between two (P3) and 36 (P5), between 0 (P5) and 66 (P1), between eight (P3) and 73 (P2), and between four (P5) and 92 (P4), respectively. Similarly, in floral dip c with Agrobacterium strain LMG62 Rif ${ }^{\mathrm{T}}$ (pMP90, pTJK136), 20 transformants were obtained out of 2,000 seeds from P1, while 101 transformants were obtained from 2,000 P5 seeds, corresponding to the highest mean transformation frequency $(2.4 \%)$ found in all the experiments shown for ecotype Col-0 in Table 2. On the other hand, with the same strain, only a mean transformation frequency of $0.16 \%$ was found in experiment a, more than tenfold lower than the $2.4 \%$ frequency found in experiment c. Also, using Agrobacterium strain LMG201 Rif $^{\mathrm{T}}$ (pMP90, pTJK136), the transformation efficiency per plant varied between eight (P5) and 50 (P2) transformants per 2,000 seeds in floral dip experiment a and between two (P3 and P5) and 56 (P1) in floral dip c. For some strains, such as LMG26 Rif $^{\mathrm{T}}$ (pMP90, pTJK136) and LBA4404 (pTJK136), the transformation variability from plant to plant within an experiment and between different experiments 
was lower, but this corresponded to the strains that showed a low number of transformants.

In conclusion, a large transformation variability was observed from plant to plant within an experiment as well as between the different biological repeats. All floral dip repeats were, however, carried out in the same conditions (i.e., temperature, surfactant concentration, inoculation time) and the only differences were the Agrobacterium inoculums and the individual

Table 2. Number of transformants among 2,000 seeds of T1 seed stocks obtained after floral dip transformation of five Arabidopsis thaliana plants from two different ecotypes using different Agrobacterium strains

\begin{tabular}{|c|c|c|c|c|c|c|c|c|}
\hline \multirow[b]{2}{*}{ Ecotype/Agrobacterium strain $^{a}$} & \multirow[b]{2}{*}{ Floral dip } & \multicolumn{5}{|c|}{ Number of transformants ${ }^{b}$} & \multirow[b]{2}{*}{$\operatorname{MTF}(\%)^{\mathrm{c}}$} & \multirow[b]{2}{*}{$\mu(\mathrm{SE})^{\mathrm{d}}$} \\
\hline & & P1 & $\mathbf{P 2}$ & P3 & $\mathbf{P 4}$ & P5 & & \\
\hline \multicolumn{9}{|l|}{ Arabidopsis thaliana ecotype Col-0 } \\
\hline \multirow[t]{4}{*}{ C58C1 Rifr (pMP90, pTJK136) } & a & 14 & 18 & 2 & 6 & 36 & 0.76 & $25.3(3.0)$ \\
\hline & $\mathrm{b}$ & 66 & 40 & 12 & 22 & 0 & 1.4 & \\
\hline & $\mathrm{c}$ & 14 & 73 & 8 & 21 & 16 & 1.32 & \\
\hline & d & 17 & 8 & 36 & 92 & 4 & 1.57 & \\
\hline \multirow{2}{*}{ C58C1 Rif ${ }^{\mathrm{r}}$ (pGV2260, pTJK136) } & $\mathrm{c}$ & 8 & 11 & 12 & 3 & 35 & 0.69 & $13.7(0.1)$ \\
\hline & $\mathrm{d}$ & 10 & 18 & 8 & 27 & 5 & 0.68 & \\
\hline \multirow{3}{*}{ C58C1 Ecm ${ }^{\mathrm{r}}(\mathrm{pMP} 90, \mathrm{pTJK} 136)$} & $\mathrm{a}$ & 2 & 6 & 2 & 0 & 0 & 0.1 & $5.8(2.0)$ \\
\hline & $\mathrm{b}$ & 10 & 4 & 16 & 16 & 6 & 0.52 & \\
\hline & $\mathrm{c}$ & 1 & 5 & 3 & 5 & 11 & 0.25 & \\
\hline \multirow{3}{*}{ LMG201 Rif ${ }^{\mathrm{r}}$ (pMP90, pTJK136) } & $\mathrm{a}$ & 22 & 50 & 20 & 22 & 8 & 1.22 & $31.5(5.8)$ \\
\hline & $\mathrm{b}$ & 38 & 98 & 62 & 18 & 12 & 2.28 & \\
\hline & $\mathrm{c}$ & 56 & 18 & 2 & 44 & 2 & 1.22 & \\
\hline \multirow[t]{3}{*}{ LMG26 Rif ${ }^{\mathrm{r}}$ (pMP90, pTJK136) } & $\mathrm{a}$ & 6 & 2 & 0 & 0 & 2 & 0.1 & $3.4(0.8)$ \\
\hline & $\mathrm{b}$ & 2 & 14 & 2 & 8 & 0 & 0.26 & \\
\hline & $\mathrm{c}$ & 1 & 0 & 9 & 2 & 3 & 0.15 & \\
\hline \multirow{3}{*}{ LMG148 Rif ${ }^{\mathrm{r}}$ (pMP90, pTJK136) } & $\mathrm{a}$ & 0 & 0 & 0 & 0 & 0 & 0 & $10.5(5.0)$ \\
\hline & $\mathrm{b}$ & 2 & 40 & 0 & 0 & 10 & 0.52 & \\
\hline & c & 5 & 0 & 2 & 32 & 67 & 1.06 & \\
\hline \multirow[t]{3}{*}{ LMG62 Rif ${ }^{\mathrm{r}}$ (pMP90, pTJK136) } & a & 2 & 4 & 0 & 0 & 10 & 0.16 & 24.4 (10.6) \\
\hline & $\mathrm{b}$ & 38 & 2 & 8 & 36 & 26 & 1.1 & \\
\hline & $\mathrm{c}$ & 20 & 64 & 28 & 27 & 101 & 2.4 & \\
\hline \multirow[t]{3}{*}{ LMG147 Rif ${ }^{\mathrm{r}}$ (pMP90, pTJK136) } & a & 2 & 2 & 0 & 6 & 4 & 0.14 & $16.9(6.7)$ \\
\hline & b & 14 & 44 & 10 & 6 & 8 & 0.82 & \\
\hline & $\mathrm{c}$ & 16 & 29 & 4 & 26 & 82 & 1.57 & \\
\hline \multirow[t]{3}{*}{ LMG142 Rif ${ }^{\mathrm{r}}$ (pMP90, pTJK136) } & $\mathrm{a}$ & 6 & 0 & 4 & 4 & 0 & 0.14 & $8.1(2.4)$ \\
\hline & $\mathrm{b}$ & 26 & 0 & 12 & 4 & 0 & 0.42 & \\
\hline & $\mathrm{c}$ & 3 & 28 & 10 & 14 & 10 & 0.65 & \\
\hline LMG232 Rif ${ }^{\mathrm{r}}$ (pMP90, pTJK136) & a & 28 & 16 & 10 & 20 & 0 & 0.74 & $13.8(2.6)$ \\
\hline & $\mathrm{b}$ & 8 & 2 & 32 & 6 & 46 & 0.94 & \\
\hline & $\mathrm{c}$ & 8 & 2 & 25 & 3 & 1 & 0.39 & \\
\hline LBA4404 (pTJK136) & a & 8 & 0 & 12 & 0 & 0 & 0.2 & $2.9(0.7)$ \\
\hline & $\mathrm{b}$ & 2 & 8 & 2 & 2 & 4 & 0.18 & \\
\hline & $\mathrm{c}$ & 2 & 0 & 4 & 0 & 0 & 0.06 & \\
\hline Arabidopsis thaliana ecotype C24 & & & & & & & & \\
\hline C58C1 Rif ${ }^{\mathrm{r}}$ (pMP90, pTJK136) & $\mathrm{c}$ & 22 & 0 & 1 & 9 & 1 & 0.33 & $4.2(1.7)$ \\
\hline & $\mathrm{d}$ & 0 & 0 & 1 & 3 & 5 & 0.09 & \\
\hline C58C1 Rif ${ }^{\mathrm{r}}$ (pGV2260, pTJK136) & c & 0 & 0 & 1 & 1 & 0 & 0.02 & $0.3(0.1)$ \\
\hline & d & 0 & - & 1 & 0 & 0 & 0.01 & \\
\hline C58C1 Ecm (pMP90, pTJK136) & $\mathrm{c}$ & 0 & 8 & 2 & 1 & 0 & 0.11 & $1.2(0.7)$ \\
\hline & $\mathrm{d}$ & 0 & 0 & 0 & 1 & 0 & 0.01 & \\
\hline LMG201 Rif ${ }^{\mathrm{r}}$ (pMP90, pTJK136) & $\mathrm{c}$ & 3 & 2 & 2 & 3 & 0 & 0.1 & $1.3(0.5)$ \\
\hline & $\mathrm{d}$ & 1 & 1 & 1 & 0 & 0 & 0.03 & \\
\hline LMG26 Rif $^{\mathrm{r}}$ (pMP90, pTJK136) & c & 0 & 0 & 0 & 0 & 0 & 0 & I \\
\hline & $\mathrm{d}$ & 0 & 0 & 0 & 0 & 0 & 0 & \\
\hline LMG148 Rif ${ }^{\mathrm{r}}$ (pMP90, pTJK136) & $\mathrm{c}$ & 0 & 3 & 1 & 0 & 18 & 0.22 & $2.6(1.3)$ \\
\hline & $\mathrm{d}$ & 0 & 0 & 3 & 1 & 0 & 0.04 & \\
\hline LMG62 Rif ${ }^{\mathrm{r}}$ (pMP90, pTJK136) & c & 0 & 8 & 0 & 0 & 0 & 0.08 & $2.2(0.5)$ \\
\hline & $\mathrm{d}$ & 3 & 0 & - & 4 & 5 & 0.12 & \\
\hline LMG147 Rif ${ }^{\mathrm{r}}$ (pMP90, pTJK136) & c & 2 & 1 & 1 & 11 & 0 & 0.15 & $1.7(0.9)$ \\
\hline & $\mathrm{d}$ & 0 & 0 & 0 & 1 & 1 & 0.02 & \\
\hline LMG142 Rif ${ }^{\mathrm{r}}$ (pMP90, pTJK136) & $\mathrm{c}$ & 0 & 0 & 1 & 0 & 0 & 0.01 & $0.1(0.1)$ \\
\hline & $\mathrm{d}$ & 0 & 0 & 0 & 0 & 0 & 0 & \\
\hline LMG232 Rif (pMP90, pTJK136) & $\mathrm{c}$ & 0 & 1 & 1 & 0 & 0 & 0.02 & $0.9(0.4)$ \\
\hline & d & 0 & 0 & - & 6 & 0 & 0.06 & \\
\hline LBA4404 (pTJK136) & $\mathrm{c}$ & 0 & 1 & 0 & 1 & 0 & 0.02 & $0.2(0.1)$ \\
\hline & $\mathrm{d}$ & 0 & 0 & 0 & 0 & 0 & 0 & \\
\hline
\end{tabular}

${ }^{a}$ All strains carried the pTJK136 binary vector and the nopaline pMP90 or octopine pGV2260 vir helper plasmid except for LBA4404, which has its own vir plasmid.

b Each Agrobacterium culture was used to floral dip five different plants (P1, P2, P3, P4, and P5) of either ecotype Col-0 or C24 in two, three, or four independent experiments $(\mathrm{a}, \mathrm{b}, \mathrm{c}, \mathrm{d})$. Seeds $(n=2,000)$ from the T1 seed stock obtained from each dipped plant were sown on kanamycin selective medium and the number of resistant plants was scored. - indicates the experiment could not be performed because there were not enough seeds.

${ }^{\mathrm{c}} \mathrm{MTF}=$ mean transformation frequency calculated as follows: [(sum of transformants within the repeat $\left.) /(5 \times 2,000)\right] \times 100$.

${ }^{\mathrm{d}} \mu=$ estimated mean counts; $\mathrm{SE}=$ standard error. 
Arabidopsis Col-0 plants that were dipped. However, the concentrations of the different Agrobacterium cultures ranged from $5.2 \times 10^{7}$ to $7.7 \times 10^{8}$ bacteria per milliliter, and no correlation between the bacterial densities and the transformation frequencies was observed. Additionally, within one biological repeat, dipping occurred with the same bacterial culture. These results suggest that the variability within and across the different performed repeats is mainly determined by the dipped plant.

None of the Agrobacterium strains yielded a higher number of floral dip transformants than the C58C1 Rif ${ }^{\mathrm{R}}$ (pMP90, pTJK136) reference strain, but several yielded

a lower number of transformants.

To compare the transformation efficiency of different Agrobacterium strains, a generalized estimating equation approach was used (Table 2). From this analysis, it is clear that none of the strains analyzed performed significantly better than the reference strain $(P$ value type III test $=0.09)$. Strain LMG201 Rif $^{\mathrm{r}}$ (pMP90, pTJK136) is estimated to yield a higher number of transformants than the reference strain C58C1 Rif ${ }^{\mathrm{r}}$ (pMP90, pTJK136), i.e., 32 compared with 25 transformants per 2,000 seeds, respectively, but the difference is not significant. Strain LMG62 Rif ${ }^{\mathrm{r}}$ (pMP90, pTJK136) is expected to yield a similar number of transformants and all other LMG strains a lower number of transformants than the reference strain, although not at a statistically significant level (Table 2).

Not only the Agrobacterium strain itself but, also, both the vir helper plasmid and mutations in the bacterial chromosome influence the floral dip transformation frequencies. Whereas the Agrobacterium strain C58C1 Rif ${ }^{\mathrm{r}}$ (pMP90, pTJK136) reference strain is estimated to yield 25 transformants in 2,000 seeds, the same C58C1 Rif ${ }^{\mathrm{r}}$ strain but harboring the octopine pGV2260 vir plasmid yields only about half the number of transformants. Even more striking is that the same chromosomal background, vir plasmid and T-DNA vector but with chromosomal mutations resulting in erythromycin and chloramphenicol resistance [C58C1 $\mathrm{Ecm}^{\mathrm{r}}$ (pMP90, pTJK136)] instead of rifampicin resistance, is expected to give only six transformants per 2,000 seeds (Table 2).

\section{Floral dip transformation}

of the Arabidopsis thaliana $\mathrm{C} 24$ ecotype is very inefficient.

For floral dip transformation of Arabidopsis thaliana ecotype C24 plants, the same Agrobacterium cultures were used as those used in one (c) or two (d) of the floral dip transformation experiments of Col-0 (Table 2). Again, no significant strain effect was detected at the 0.05 significance level ( $P$ value type III test $=0.47$ ), and the obtained mean transformation frequencies among 2,000 seeds of five plants were low for all bacterial strains and varied between 0 and $0.33 \%$ (Table 2). Especially remarkable is that the cultures that gave a high transformation frequency in the Col-0 ecotype [C58C1 Rif (pMP90, pTJK136), LMG201 Rif ${ }^{\mathrm{r}}$ (pMP90, pTJK136), and LMG62 Rif ${ }^{\mathrm{r}}$ (pMP90, pTJK136); Table 2] gave very few transformants in the C24 ecotype. This indicates that Arabidopsis thaliana ecotype C24 is to some extent recalcitrant to Agrobacterium floral dip transformation.

\section{Floral dip cotransformation experiments reveal that the inter-plant variability is larger than the intra-plant variability of transformation frequencies of two Agrobacterium strains.}

In order to assess the influence of different Agrobacterium strains on the Arabidopsis thaliana transformation efficiency in more detail and to overcome the inter-plant variability within one experiment, several cotransformation experiments of Arabidopsis Col-0 plants were performed using a mixture of two different Agrobacterium strains. In the cotransformation experiments presented in Table 3, strains C58C1 Rif ${ }^{\mathrm{T}}$ (pMP90), LMG62 Rif $^{\mathrm{r}}$ (pMP90), and LMG201 Rif ${ }^{\mathrm{r}}$ (pMP90) were used as reference strains. These reference strains all contained the pAAVS1 binary vector, carrying the hygromycin phosphotransferase gene and they were combined in the cocultivation mixture with each other or with the Agrobacterium strains LBA4404, LBA4404 (virGN54D), EHA101, and AGL1, all carrying the pTJK136 binary vector with the kanamycin-resistance gene (Table 3). Strain LBA4404 (virGN54D) is an LBA4404 strain supplemented with a constitutive $\operatorname{vir} G$ mutant gene (virGN54D) on a compatible plasmid (van der Fits et al. 2000). Agrobacterium strain EHA101 is derived from a cured C58C1 Rif $^{\mathrm{r}}$ strain and harbors a vir plasmid derived from pTiBo542, isolated from Agrobacterium strain A281, disarmed by substitution of the T-DNA region with a kanamycin-resistance gene (Hood et al. 1986). Agrobacterium strain AGL1 is a derivative of strain EHA101 but carries an insertion mutation in its recA recombination gene to stabilize recombinant plasmids (Lazo et al. 1991).

From the results in these four series of cotransformation experiments, a number of conclusions can be formulated. First and most importantly, a comparable number of kanamycinand hygromycin-resistant transformants was obtained when a strain with the same chromosomal background and vir plasmid but containing another T-DNA plasmid (pTJK136 and pAAVS1, respectively) was used (Table 3 , rows $1,5,13$, and 21 ). This shows that the inter-plant variability can be distinguished from the variability imposed by the strain. Secondly and very strikingly, the number of transformants obtained with the LBA4404 (pTJK136) or LBA4404 (virGN54D, pTJK136) strains was very low (0 to 3 in 1,000 seeds) for all dipped plants (Table 3, rows 4, 8 and 9, 15, and 16, 22 and 23). From the four cotransformation experiments with strain LBA4404 and the three cotransformation experiments with strain LBA4404 (virGN54D), only 11 transformants in 20,000 seeds $(0.06 \%)$ and two transformants in 15,000 seeds $(0.01 \%)$ could be obtained, respectively. These results corroborate those given in Table 2 showing that the LBA4404 strain is significantly $(\alpha=0.1)$ less efficient in three out of four cotransformation experiments of the Arabidopsis thaliana Col-0 ecotype. The fact that one cotransformation experiment (Table 3, row 15) is not significant is probably due to less available data points and missing observations for the fifth plant. Thirdly, floral dip with the AGL1 (pTJK136) strain results in significantly $(\alpha=0.1)$ fewer transformants, although this strain has the same C58-derived chromosomal background and vir plasmid as the reference strain C58C1 Rif $^{\mathrm{r}}$ (pMP90, pAAVS1) (Table 3, row 11). Fourthly, the transformation efficiency of the LMG62 Rif $^{\mathrm{r}}$ (pMP90) strain was a bit lower than that of the C58C1 Rif ${ }^{\mathrm{r}}$ (pMP90) strain in 10 of the 15 cotransformed plants (Table 3, rows 2, 6, and 12), while the number of transformants obtained with the C58C1 Rif ${ }^{\mathrm{r}}$ (pMP90) and LMG201 Rif ${ }^{\mathrm{r}}$ (pMP90) strains was very comparable in all 15 cotransformed plants (Table 3, rows 3,7 , and 19). Finally, in these cotransformation experiments, a high inter-plant variability within one experiment using the same bacterial mixture was observed, confirming our previous conclusion that the physiology and the developmental stage of the dipped plants highly influence the transformation frequencies during floral dip transformation.

\section{Transformation with LMG201 Rif ${ }^{r}$ (pMP90, pTJK136) results in transformants with a similar T-DNA integration pattern as C58C1 Rif $^{\mathrm{r}}$ (pMP90, pTJK136).}

Since Agrobacterium strain LMG201 Rif (pMP90, pTJK136) showed similar transformation frequencies as C58C1 Rif 
Table 3. Number of kanamycin- and hygromycin-resistant transformants among 1,000 seeds obtained after Arabidopsis Col-0 floral dip co-transformation using Agrobacterium strain mixtures

\begin{tabular}{|c|c|c|c|c|c|c|c|c|}
\hline \multirow{2}{*}{\multicolumn{2}{|c|}{ Reference strain/row no./Agrobacterium mixtures ${ }^{\mathrm{a}}$}} & \multicolumn{5}{|c|}{ Number of transformants ${ }^{b}$} & \multirow[b]{2}{*}{$\operatorname{MTF}(\%)^{\mathrm{c}}$} & \multirow[b]{2}{*}{$P$ value } \\
\hline & & $\mathbf{P 1}$ & $\mathbf{P 2}$ & $\mathbf{P 3}$ & $\mathbf{P 4}$ & P5 & & \\
\hline \multicolumn{9}{|c|}{ Pilot experiment; C58C1 Rif ${ }^{\mathrm{r}}$ (pMP90, pAAVS1) } \\
\hline 1 & $\begin{array}{l}\text { C58C1 } \text { Rif }^{\mathrm{r}}(\mathrm{pMP} 90, \text { pTJK136) } \\
\text { C58C1 } \text { Rif }^{\mathrm{r}}(\mathrm{pMP} 90, \text { pAAVS1) }\end{array}$ & $\begin{array}{l}23 \\
24\end{array}$ & $\begin{array}{l}20 \\
24\end{array}$ & $\begin{array}{l}18 \\
12\end{array}$ & $\begin{array}{l}9 \\
8\end{array}$ & $\begin{array}{l}3 \\
2\end{array}$ & $\begin{array}{l}1.46 \\
1.4\end{array}$ & 0.81 \\
\hline 2 & $\begin{array}{l}\text { LMG62 Rifr (pMP90, pTJK136) } \\
\text { C58C1 Rifr (pMP90, pAAVS1) }\end{array}$ & $\begin{array}{r}107 \\
45\end{array}$ & $\begin{array}{l}30 \\
19\end{array}$ & $\begin{array}{l}20 \\
22\end{array}$ & $\begin{array}{l}3 \\
5\end{array}$ & $\begin{array}{l}82 \\
20\end{array}$ & $\begin{array}{l}4.84 \\
2.22\end{array}$ & 0.31 \\
\hline 3 & $\begin{array}{l}\text { LMG201 Rif }{ }^{\mathrm{r}}(\mathrm{pMP} 90, \text { pTJK136) } \\
\text { C58C1 Rif }{ }^{\mathrm{p}} \text { (pM90, pAAVS1) }\end{array}$ & $\begin{array}{l}20 \\
13\end{array}$ & $\begin{array}{l}27 \\
18\end{array}$ & $\begin{array}{l}27 \\
26\end{array}$ & $\begin{array}{l}43 \\
36\end{array}$ & $\begin{array}{l}37 \\
28\end{array}$ & $\begin{array}{l}3.08 \\
2.42\end{array}$ & 0.06 \\
\hline 4 & $\begin{array}{l}\text { LBA4404 (pTJK136) } \\
\text { C58C1 Rif }{ }^{\text {pMP90, pAAVS1) }}\end{array}$ & $\begin{array}{r}0 \\
14\end{array}$ & $\begin{array}{r}1 \\
101\end{array}$ & $\begin{array}{l}0 \\
6\end{array}$ & $\begin{array}{r}0 \\
12\end{array}$ & $\begin{array}{l}0 \\
3\end{array}$ & $\begin{array}{l}0.02 \\
2.72\end{array}$ & 0.06 \\
\hline \multicolumn{9}{|c|}{ Strain C58C1 Rif ${ }^{\mathrm{r}}$ (pMP90, pAAVS1) } \\
\hline 5 & $\begin{array}{l}\text { C58C1 } \text { Rif }^{\mathrm{r}}(\mathrm{pMP} 90, \text { pTJK136) } \\
\text { C58C1 Rif }{ }^{\mathrm{r}}(\mathrm{pMP} 90, \text { pAAVS1) }\end{array}$ & $\begin{array}{r}12 \\
7\end{array}$ & $\begin{array}{l}23 \\
18\end{array}$ & $\begin{array}{l}3 \\
2\end{array}$ & $\begin{array}{l}5 \\
5\end{array}$ & $\begin{array}{l}19 \\
16\end{array}$ & $\begin{array}{l}1.24 \\
0.96\end{array}$ & 0.13 \\
\hline 6 & $\begin{array}{l}\text { LMG62 Rifr (pMP90, pTJK136) } \\
\text { C58C1 Rifr (pMP90, pAAVS1) }\end{array}$ & $\begin{array}{l}1 \\
8\end{array}$ & $\begin{array}{l}4 \\
4\end{array}$ & $\begin{array}{r}3 \\
10\end{array}$ & $\begin{array}{l}5 \\
9\end{array}$ & $\begin{array}{l}17 \\
17\end{array}$ & $\begin{array}{l}0.6 \\
0.96\end{array}$ & 0.25 \\
\hline 7 & $\begin{array}{l}\text { LMG201 Rif }{ }^{\mathrm{r}} \text { (pMP90, pTJK136) } \\
\text { C58C1 Rif }{ }^{\mathrm{p}} \text { (pM90, pAAVS1) }\end{array}$ & $\begin{array}{l}21 \\
16\end{array}$ & $\begin{array}{r}8 \\
10\end{array}$ & $\begin{array}{r}8 \\
13\end{array}$ & $\begin{array}{l}21 \\
24\end{array}$ & $\begin{array}{l}5 \\
4\end{array}$ & $\begin{array}{l}1.26 \\
1.34\end{array}$ & 0.69 \\
\hline 8 & $\begin{array}{l}\text { LBA4404 (pTJK136) } \\
\text { C58C1 Rif }{ }^{\mathrm{r}} \text { (pMP90, pAAVS1) }\end{array}$ & $\begin{array}{r}1 \\
21\end{array}$ & $\begin{array}{l}2 \\
5\end{array}$ & $\begin{array}{r}2 \\
29\end{array}$ & $\begin{array}{l}0 \\
2\end{array}$ & $\begin{array}{l}0 \\
4\end{array}$ & $\begin{array}{l}0.1 \\
1.22\end{array}$ & 0.06 \\
\hline 9 & $\begin{array}{l}\text { LBA4404 (virGN54D, pTJK136) } \\
\text { C58C1 Rif }{ }^{\mathrm{r}} \text { (pMP90, pAAVS1) }\end{array}$ & $\begin{array}{r}0 \\
13\end{array}$ & $\begin{array}{r}0 \\
15\end{array}$ & $\begin{array}{r}1 \\
23\end{array}$ & $\begin{array}{r}0 \\
29\end{array}$ & $\begin{array}{l}0 \\
3\end{array}$ & $\begin{array}{l}0.02 \\
1.66\end{array}$ & 0.06 \\
\hline 10 & $\begin{array}{l}\text { EHA101 (pTJK136) } \\
\text { C58C1 Rif }{ }^{\mathrm{r}}(\mathrm{pMP} 90, \text { pAAVS1) }\end{array}$ & $\overline{3}$ & $\begin{array}{r}9 \\
20\end{array}$ & $\begin{array}{l}7 \\
3\end{array}$ & $\begin{array}{l}14 \\
12\end{array}$ & $\begin{array}{l}12 \\
12\end{array}$ & $\begin{array}{l}1.05 \\
1\end{array}$ & 1.00 \\
\hline 11 & $\begin{array}{l}\text { AGL1 (pTJK136) } \\
\text { C58C1 } \text { Rif }^{\mathrm{r}}(\mathrm{pMP} 90, \mathrm{pAAVS} 1)\end{array}$ & $\begin{array}{r}6 \\
13\end{array}$ & $\begin{array}{l}2 \\
5\end{array}$ & $\begin{array}{l}2 \\
8\end{array}$ & $\begin{array}{r}0 \\
32\end{array}$ & $\begin{array}{l}0 \\
8\end{array}$ & $\begin{array}{l}0.2 \\
1.32\end{array}$ & 0.06 \\
\hline \multicolumn{9}{|c|}{ Strain LMG62 Rif ${ }^{\mathrm{r}}$ (pMP90, pAAVS1) } \\
\hline & $\begin{array}{l}\text { C58C1 Rif }{ }^{\mathrm{r}}(\mathrm{pMP} 90, \text { pTJK136) } \\
\text { LMG62 Rifr (pMP90, pAAVS1) }\end{array}$ & $\begin{array}{l}8 \\
2\end{array}$ & $\begin{array}{r}25 \\
9\end{array}$ & $\begin{array}{r}16 \\
3\end{array}$ & $\begin{array}{l}60 \\
29\end{array}$ & $\begin{array}{l}14 \\
10\end{array}$ & $\begin{array}{l}2.46 \\
1.06\end{array}$ & 0.06 \\
\hline 13 & $\begin{array}{l}\text { LMG62 Rif }{ }^{\mathrm{r}} \text { (pMP90, pTJK136) } \\
\text { LMG62 Rif }{ }^{\mathrm{r}} \text { (pMP90, pAAVS1) }\end{array}$ & $\begin{array}{l}6 \\
3\end{array}$ & $\begin{array}{l}3 \\
3\end{array}$ & $\begin{array}{r}16 \\
8\end{array}$ & $\begin{array}{l}21 \\
12\end{array}$ & $\begin{array}{l}6 \\
3\end{array}$ & $\begin{array}{l}1.04 \\
0.58\end{array}$ & 0.13 \\
\hline 14 & $\begin{array}{l}\text { LMG201 Rif (pMP90, pTJK136) } \\
\text { LMG62 Rif }{ }^{\mathrm{r}}(\mathrm{pMP90,} \mathrm{pAAVS1)}\end{array}$ & $\begin{array}{l}36 \\
10\end{array}$ & $\begin{array}{r}6 \\
10\end{array}$ & $\begin{array}{l}17 \\
10\end{array}$ & $\begin{array}{r}11 \\
3\end{array}$ & $\begin{array}{l}9 \\
8\end{array}$ & $\begin{array}{l}1.58 \\
0.82\end{array}$ & 0.19 \\
\hline 15 & $\begin{array}{l}\text { LBA4404 (pTJK136) } \\
\text { LMG62 Rif }^{\text {(pMP90, pAAVS1) }}\end{array}$ & $\begin{array}{r}0 \\
31\end{array}$ & $\begin{array}{r}2 \\
12\end{array}$ & $\begin{array}{l}0 \\
3\end{array}$ & $\begin{array}{r}0 \\
25\end{array}$ & $\begin{array}{l}- \\
-\end{array}$ & $\begin{array}{l}0.05 \\
1.77\end{array}$ & 0.13 \\
\hline 16 & $\begin{array}{l}\text { LBA4404 (virGN54D, pTJK136) } \\
\text { LMG62 } \text { Rif }^{\mathrm{r}}(\mathrm{pMP90,pAAS1)}\end{array}$ & $\begin{array}{l}0 \\
4\end{array}$ & $\begin{array}{l}0 \\
7\end{array}$ & $\begin{array}{l}0 \\
4\end{array}$ & $\begin{array}{l}0 \\
1\end{array}$ & $\begin{array}{l}- \\
-\end{array}$ & $\begin{array}{l}0 \\
0.4\end{array}$ & 0.13 \\
\hline 17 & $\begin{array}{l}\text { EHA101 (pTJK136) } \\
\text { LMG62 Rif }{ }^{\mathrm{r}} \text { (pMP90, pAAVS1) }\end{array}$ & $\begin{array}{r}18 \\
3\end{array}$ & $\begin{array}{l}3 \\
0\end{array}$ & $\begin{array}{r}16 \\
3\end{array}$ & $\begin{array}{l}6 \\
4\end{array}$ & $\begin{array}{l}4 \\
1\end{array}$ & $\begin{array}{l}0.94 \\
0.22\end{array}$ & 0.06 \\
\hline 18 & $\begin{array}{l}\text { AGL1 (pTJK136) } \\
\text { LMG62 Rif }{ }^{\mathrm{r}} \text { (pMP90, pAAVS1) }\end{array}$ & $\begin{array}{l}14 \\
12\end{array}$ & $\begin{array}{r}10 \\
8\end{array}$ & $\begin{array}{l}6 \\
2\end{array}$ & $\begin{array}{l}3 \\
1\end{array}$ & $\begin{array}{l}13 \\
10\end{array}$ & $\begin{array}{l}0.92 \\
0.66\end{array}$ & 0.06 \\
\hline \multicolumn{9}{|c|}{ Strain LMG201 Rif ${ }^{\mathrm{r}}$ (pMP90, pAAVS1) } \\
\hline 19 & $\begin{array}{l}\text { C58C1 Rif }{ }^{\mathrm{r}}(\mathrm{pMP} 90, \text { pTJK136) } \\
\text { LMG201 Rif }{ }^{\mathrm{r}}(\mathrm{pMP90,} \text { pAAVS1) }\end{array}$ & $\begin{array}{l}2 \\
0\end{array}$ & $\begin{array}{l}1 \\
7\end{array}$ & $\begin{array}{l}33 \\
27\end{array}$ & $\begin{array}{r}18 \\
8\end{array}$ & $\begin{array}{l}7 \\
5\end{array}$ & $\begin{array}{l}1.22 \\
0.94\end{array}$ & 0.38 \\
\hline 20 & $\begin{array}{l}\text { LMG62 Rif }{ }^{\mathrm{r}}(\mathrm{pMP} 90, \text { pTJK136) } \\
\text { LMG201 Rif }^{\mathrm{r}}(\mathrm{pMP90,} \text { pAAVS1) }\end{array}$ & $\begin{array}{l}1 \\
4\end{array}$ & $\begin{array}{l}7 \\
5\end{array}$ & $\begin{array}{l}18 \\
12\end{array}$ & $\begin{array}{l}32 \\
23\end{array}$ & $\begin{array}{l}31 \\
26\end{array}$ & $\begin{array}{l}1.78 \\
1.4\end{array}$ & 0.19 \\
\hline 21 & $\begin{array}{l}\text { LMG201 Rifr }(\text { pMP90, pTJK136) } \\
\text { LMG201 Rif }^{\mathrm{r}}(\text { pMP90, pAAVS1) }\end{array}$ & $\begin{array}{l}21 \\
26\end{array}$ & $\begin{array}{l}4 \\
8\end{array}$ & $\begin{array}{l}20 \\
28\end{array}$ & $\begin{array}{l}21 \\
22\end{array}$ & $\begin{array}{l}28 \\
24\end{array}$ & $\begin{array}{l}1.88 \\
2.16\end{array}$ & 0.25 \\
\hline 22 & $\begin{array}{l}\text { LBA4404 (pTJK136) } \\
\text { LMG201 Rif }{ }^{\mathrm{r}}(\mathrm{pMP90,} \text { pAAVS1) }\end{array}$ & $\begin{array}{r}0 \\
20\end{array}$ & $\begin{array}{l}0 \\
6\end{array}$ & $\begin{array}{r}0 \\
12\end{array}$ & $\begin{array}{r}3 \\
43\end{array}$ & $\begin{array}{l}0 \\
2\end{array}$ & $\begin{array}{l}0.06 \\
1.66\end{array}$ & 0.06 \\
\hline 23 & $\begin{array}{l}\text { LBA4404 (virGN54D, pTJK136) } \\
\text { LMG201 Rif }{ }^{\mathrm{r}}(\mathrm{pMP} 90, \text { pAAVS1) }\end{array}$ & $\begin{array}{r}0 \\
20\end{array}$ & $\begin{array}{r}1 \\
13\end{array}$ & $\begin{array}{r}0 \\
32\end{array}$ & $\begin{array}{l}0 \\
3\end{array}$ & $\begin{array}{r}0 \\
12\end{array}$ & $\begin{array}{l}0.02 \\
1.6\end{array}$ & 0.06 \\
\hline 24 & $\begin{array}{l}\text { EHA101 (pTJK136) } \\
\text { LMG201 Rif }{ }^{\mathrm{r}}(\mathrm{pMP} 90, \mathrm{pAAVS1})\end{array}$ & $\begin{array}{l}7 \\
9\end{array}$ & $\begin{array}{l}0 \\
5\end{array}$ & $\begin{array}{r}9 \\
15\end{array}$ & $\begin{array}{l}3 \\
3\end{array}$ & $\begin{array}{l}1 \\
6\end{array}$ & $\begin{array}{l}0.4 \\
0.76\end{array}$ & 0.13 \\
\hline & $\begin{array}{l}\text { AGL1 (pTJK136) } \\
\text { LMG201 Rif }{ }^{\mathrm{r}}(\mathrm{pMP} 90, \mathrm{pAAVS} 1)\end{array}$ & $\begin{array}{r}9 \\
26\end{array}$ & $\begin{array}{r}4 \\
23\end{array}$ & $\begin{array}{l}1 \\
6\end{array}$ & $\begin{array}{r}6 \\
11\end{array}$ & $\begin{array}{l}1 \\
5\end{array}$ & $\begin{array}{l}0.42 \\
1.42\end{array}$ & 0.06 \\
\hline
\end{tabular}

${ }^{a}$ Within one mixture, the variable strain carries the pTJK136 T-DNA with the kanamycin resistance gene, while the reference strain carries the pAAVS1 T-DNA with the hygromycin resistance gene. The variable strains used in the strain C58C1 Rif (pMP90, pAAVS1) mixtures are derived from the same culture as the ones used in the strain LMG62 Rif ${ }^{\mathrm{r}}$ (pMP90, pAAVS1) mixtures.

${ }^{\mathrm{b}} \mathrm{P} 1$ to P5 designate five different dipped Arabidopsis thaliana Col-0 plants. - indicates the experiment could not be performed because there were not enough seeds.

${ }^{\mathrm{c}} \mathrm{MTF}=$ mean transformation frequency, calculated as follows: [(sum of transformants within the repeat $\left.) /(5 \times 1,000)\right] \times 100$. At the $5 \%$ significance level, no significant difference is computated, but at the 10\% significance level, the significant differences appear in bold, e.g., in the pilot experiment, LBA4404 (pTJK136) has significantly fewer and LMG201 Rif ${ }^{\mathrm{r}}$ (pMP90, pTJK136) significantly more counts than reference strain C58C1 Rif ${ }^{\mathrm{r}}$ (pMP90, pAAVS1), and in the second experiment shown, three lines (LBA4404 (pTJK136), LBA4404 (virGN54D, pTJK136), and AGL1 (pTJK136)) have significantly fewer transformants as compared with the reference strain. 
(pMP90, pTJK136) after floral dip transformation of the Arabidopsis Col-0 ecotype, we decided to further explore the properties of the transformants. A pathogenicity test using wounded tobacco plants was performed to check the oncogenicity of strains LMG201, LMG201 Rif ${ }^{\mathrm{r}}$, LMG201 Rif ${ }^{\mathrm{r}}$ (pMP90), and LMG201 Rif ${ }^{\mathrm{r}}$ (pMP90, pTJK136). When the wild-type Agrobacterium strain LMG201 and the Rif ${ }^{r}$ mutant LMG201 Rif ${ }^{r}$ were applied at the wounding site, crown galls were formed (data not shown). However, no tumors were observed when LMG201 Rif ${ }^{\mathrm{r}}$ (pMP90) and LMG201 Rif ${ }^{\mathrm{r}}$ (pMP90, pTJK136) were applied on wounded tobacco stems, showing that Agrobacterium strain LMG201 Rif $^{\mathrm{r}}$ (pMP90) was no longer oncogenic and could be used to generate transgenic plants.

In order to determine whether analogous T-DNA integration patterns were obtained upon transformation with either Agrobacterium strain LMG201 Rif ${ }^{\mathrm{r}}$ (pMP90, pTJK136) or C58C1 Rif $^{\mathrm{r}}$ (pMP90, pTJK136), the locus number and the T-DNA integration pattern were determined in 31 transformants obtained after floral dip transformation of Col-0. The percentage of plants in which the T-DNA was integrated in one locus was relatively similar for both strains, 25 of 31 tested progenies (80\%) for LMG201 Rif $^{\mathrm{r}}$ (pMP90, pTJK136) and 23 of 31 progenies (74\%) for C58C1 Rif ${ }^{\mathrm{r}}$ (pMP90, pTJK136) (data not shown). DNA gel blot analysis on EcoRV-digested DNA from these transformants and hybridization with either the $G U S$ or neomycin phosphotransferase II (NPTII) probe showed no major differences between the number of integrated T-DNAs and T-DNA linkages in direct and inverted repeats. Complex T-DNA integration patterns with multiple T-DNAs were observed for both strains. Indeed, using the GUS probe (Fig. 1A), bands of $2,700 \mathrm{bp}$ and $5,300 \mathrm{bp}$ revealing the presence of inverted repeats around the right border and tandem repeats, respectively, were visualized for several transgenic plants (Fig. 1B). The tandem repeats were confirmed with the NPTII probe (data not shown).

This similarity of the T-DNA integration pattern in both LMG201 Rif ${ }^{\mathrm{T}}$ (pMP90, pTJK136) and C58C1 Rif ${ }^{\mathrm{r}}$ (pMP90, pTJK136) transformants suggests similar T-DNA expression profiles because the T-DNA copy number and configuration strongly influence the susceptibility for silencing. GUS activity measurements were performed on leaf extracts from 39 LMG201 Rif ${ }^{\mathrm{T}}$ (pMP90, pTJK136) and 26 C58C1 Rif ${ }^{\mathrm{r}}$ (pMP90, pTJK136) transformants. For both transformant series, a bimodal distribution of the GUS accumulation levels was found. In about $90 \%$ of the transformants, less than $150 \mathrm{U}$ of GUS per milligram of total soluble protein was produced, whereas, in about $10 \%$ of the transformants, the expected 200 to $300 \mathrm{U}$ of GUS per milligram of total soluble protein was found (data not shown).

In conclusion, floral dip transformation with the Agrobacterium strain LMG201 Rif $^{\mathrm{r}}$ (pMP90, pTJK136) results in transformants with a similar T-DNA integration pattern and $35 \mathrm{~S}$

A
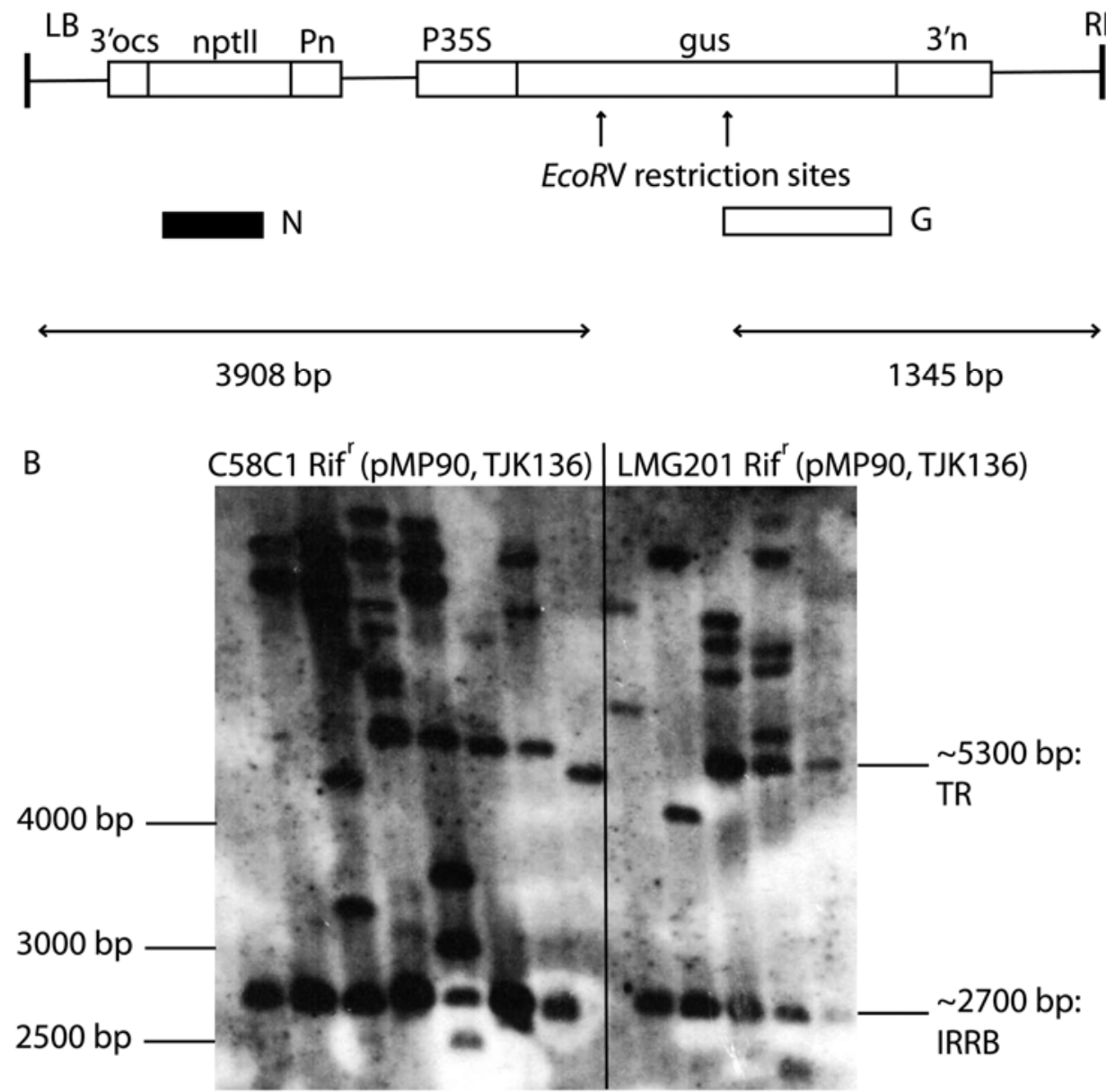

Fig. 1. DNA gel blot analysis to determine the T-DNA integration pattern in transformants obtained after cocultivation with the Agrobacterium strains C58C1 Rif $^{\mathrm{r}}$ (pMP90, pTJK136) and LMG201 Rif ${ }^{\mathrm{r}}$ (pMP90, pTJK136). Two probes were used: GUS (G) and NPTII (N). A, Schematic representation of the T-DNA harbored by the pTJK136 plasmid, the EcoRV restriction sites (not on scale), and the expected fragment length. The GUS probe used in (B) is depicted as a white bar $(\mathrm{G})$. N stands for NPTII probe. $3^{\prime} \mathrm{ocs}=3^{\prime}$ end of the octopine synthase gene, nptII = neomycin phosphotransferase II gene; Pn = promoter of the nopaline synthase gene; P35S = Cauliflower mosaic virus $35 \mathrm{~S}$ promoter; $G U S=\beta$-glucuronidase gene; $3^{\prime} \mathrm{n}=3^{\prime}$ end of the nopaline synthase gene; LB = left T-DNA border; $\mathrm{RB}=$ right T-DNA border; $\mathrm{bp}=$ base pair; $\mathbf{B}$, T-DNA integration pattern obtained using the GUS probe on DNA digested with EcoRV. TR = tandem repeat; IRRB $=$ inverted repeat around the right border. 
promoter-driven transgene expression variation as the transformants obtained with the Agrobacterium strain C58C1 Rif ${ }^{\mathrm{r}}$ (pMP90, pTJK136).

\section{DISCUSSION}

In this work, we present a comparative study of seven LMG Agrobacterium strains regarding their ability to produce transformants upon floral dip transformation of the Arabidopsis thaliana ecotypes Col-0 and C24 in comparison with the commonly used Agrobacterium strains C58C1 Rif ${ }^{\mathrm{r}}$ (pMP90) and LBA4404.

Statistical analysis showed that the Agrobacterium strains LMG201 Rif ${ }^{\mathrm{r}}$ (pMP90, pTJK136) and, to a certain extent, LMG62 Rif ${ }^{\mathrm{r}}$ (pMP90, pTJK136) have a similar Col-0 floral dip transformation performance as compared with C58C1 Rif (pMP90, pTJK136) and a better one than LBA4404 Rif ${ }^{\mathrm{r}}$ (pTJK136). Arabidopsis thaliana ecotype C24 floral dip transformation using the same bacterial strains showed low transformation frequencies (maximum $0.33 \%$ ) in two performed biological repeats. These low transformation frequencies are mainly attributed to the plant ecotype, as some strains such as LMG201 Rif ${ }^{\mathrm{r}}$ (pMP90, pTJK136) and C58C1 Rif ${ }^{\mathrm{r}}$ (pMP90, pTJK136) were very efficient during floral dip of the Arabidopsis ecotype Col-0 plants. In literature, floral dip experiments of Arabidopsis thaliana ecotype C24 plants were already performed, but none of these studies gave any indication concerning the transformation efficiencies (Broothaerts et al. 2005; Tadege et al. 2003; Truernit and Haseloff 2008; Zheng et al. 2005). However, other studies also reported that different Arabidopsis ecotypes are transformed with variable frequencies (Clough and Bent 1998; Katavic et al. 1994). Recalcitrance of some Arabidopsis ecotypes to floral dip transformation could be located at the flower level (e.g., morphology, accessibility of the ovule) but could also be caused by a difference in pathogen response activated during Agrobacterium infection (Adam et al. 1999; Citovsky et al. 2007). A better understanding of the restricting parameters might help in enabling the floral dip transformation method for recalcitrant Arabidopsis accessions and other crops.

We show that mutations in the chromosome $\left(\operatorname{Rif}^{\mathrm{r}} \mathrm{vs} . \mathrm{Ecm}^{\mathrm{r}}\right)$ or the use of different vir plasmids (pMP90 vs. pGV2260) of Agrobacterium strain $\mathrm{C} 58 \mathrm{C} 1$ clearly influence the transformation frequencies. The C58C1 Rif $^{\mathrm{T}}$ (pMP90, pTJK136) transformation frequencies were at least twofold higher than those of $\mathrm{C} 58 \mathrm{C} 1$ $\mathrm{Ecm}^{\mathrm{r}}$ (pMP90, pTJK136). This might be explained by the fact that the erythromycin- and chloramphenicol-resistance mutations most likely occurred in the genes encoding ribosomal RNA and ribosomal proteins, thereby lowering the fitness of the mutated bacteria and interfering with their growth, movement, and penetration in the ovules. Also the helper vir plasmid seems to have an influence on the floral dip transformation frequency. When using strain C58C1 Rif ${ }^{\mathrm{T}}$ with the nopaline vir plasmid pMP90, the transformation frequency was higher than that obtained using the octopine vir helper plasmid pGV2260, which could be due to the different dosage of vir gene products. Also, in other transformation protocols, the vir plasmid had an influence on transformation efficiency. Arabidopsis C24 root explant transformation with the octopine pGV2260 vir plasmid worked better with than the nopaline pMP90 plasmid in our hands (unpublished data). Thus, for every transformation method, the "best" vir plasmid should be determined. Here, seven LMG Agrobacterium strains were tested only in combination with the nopaline pMP90 vir plasmid. However, we cannot exclude the possibility that, for some of these strains, higher floral dip transformation efficiencies can be obtained when they are combined with another vir plasmid.
The high transformation frequency of LMG201 Rif (pMP90, pTJK136) was observed in all performed biological repeats of all transformation and cotransformation experiments. Therefore, the best-performing Agrobacterium strains in Arabidopsis Col-0 floral dip transformation are based on the chromosomal backgrounds of LMG201 and C58, which both belong to the genomic group G8 (Costechareyre et al. 2009; Portier et al. 2006). Upon introduction of the nopaline pMP90 vir plasmid, the pathogenic characteristic of the wild-type Agrobacterium strain LMG201 was lost, most probably due to incompatibility between the introduced nopaline vir plasmid and the resident $\mathrm{Ti}$ plasmid of LMG201. The T-DNA integration patterns upon transformation with LMG201 Rif $^{\mathrm{T}}$ (pMP90, pTJK136) were very comparable to those observed in the transformants with C58C1 Rif ${ }^{\mathrm{T}}$ (pMP90, pTJK136). This is in line with the finding that, with a particular Agrobacterium strain, the T-DNA copy numbers and integration pattern in Arabidopsis transformants were primarily determined by the target cells and were found to be more complex after floral dip transformation than after root explant transformation (De Buck et al. 2009). Additionally, the expression profile and variation of the pTJK136-encoded GUS controlled by the strong constitutive $35 \mathrm{~S}$ promoter in the transformants obtained by both strains was similar. In the majority of the transformants with complex T-DNA integration patterns, low or intermediate GUS accumulation levels were observed, while only in a minority of transformants, high GUS levels were obtained. This is similar to observations of most overexpression constructs analyzed, yielding more than a 100-fold difference in recombinant protein accumulation levels between the highest and lowest expressors (Butaye et al. 2004; De Buck and Depicker 2004; De Buck et al. 2004). The high recombinant protein accumulation levels are as expected, but the intermediate or low and unstable transgene expression was found to be due to RNA-dependent RNA polymerase 6-mediated production of double stranded RNA on the basis of aberrant RNA, resulting in posttranscriptional silencing (Butaye et al. 2004; De Buck et al. 2004). In contrast, transgenes controlled by the nopaline synthase promotor or other weak promoters display similar mRNA expression levels in the majority of transformants, most probably because the threshold level of aberrant RNA, the trigger of posttranscriptional gene silencing, is not reached (Butaye et al. 2004).

In contrast to the high transformation efficiencies obtained with the Agrobacterium strains LMG201 Rif ${ }^{\mathrm{r}}$ (pMP90, pTJK136) and C58C1 Rif ${ }^{\mathrm{r}}$ (pMP90, pTJK136) (0.76 to $1.57 \%$ and 1.22 to $3.08 \%$, respectively), only $0.02 \%$ to $0.2 \%$ were obtained when using the strain LBA4404 (pTJK136), even when supplemented with an additional constitutive virG mutant gene. Also, Oltmanns and associates (2010) found very low floral dip transformation efficiencies with LBA4404 as compared with C58C1 Rif ${ }^{\mathrm{r}}$ (pMP90) and AGL1. However LBA4404 is the preferred strain for stable transformation of many different plant species, such as maize and soybean, and also for transient Agrobacterium-mediated transformation protocols of Nicotiana benthamiana (Sainsbury et al. 2009).

Upon floral dip transformation, a high variability in transformation efficiency was observed in different dipped plants, even when the same Agrobacterium culture was used. In some dipping experiments, the number of transformants per plant even differed more than 50-fold. Also, by performing cotransformation with two similar strains, correlated transformation frequencies per seed stock for the two strains were obtained, but variable frequencies between different seed stocks were observed. Therefore, we suggest to floral dip several plants and sow fewer seeds per obtained seed stock rather than to rely on one or two dipped plants and sowing more seeds per plant to obtain the required number of transformants. 
The main target during Agrobacterium floral dip transformation is the ovule, the female tissue of Arabidopsis thaliana and, more in particular, the female gametophyte, which develops inside the ovule. T-DNA transfer and integration seems to occur at the end of the female haploid phase and before fertilization (Bechtold et al. 2000, 2003; Desfeux et al. 2000; Ye et al. 1999). The immersion of the flowers in the bacterial culture should take place a few days before anthesis, after which the Agrobacterium grows inside the developing flower, in which the ovary develops as a ring of cells extending to form a vase-shaped structure that is open at the top (Clough and Bent 1998; Desfeux et al. 2000). Only late in floral development, about three days prior to anthesis, the locules become sealed by stigma formation (WiktorekSmagur et al. 2009). Hence, for a successful transformation, it is imperative that the agrobacteria reach the immediate vicinity of the ovule and encounter the environmental conditions in which virulence operons are induced. Thus, we speculate that the variability in transformation frequencies is mainly due to the variable number of developing flowers per plant in which the ovule and, in particular, the female gametophyte are accessible to the bacteria and in which the conditions are favorable to attach to the developing female gametophyte, after which the T-DNA transfer process can start.

In conclusion, none of the seven LMG strains analyzed during Arabidopsis Col-0 floral dip transformation performed better than the commonly used C58C1 Rif ${ }^{\mathrm{r}}$ (pMP90) strain. The only strain that resulted in similar transformation efficiencies and gave rise to transformants with a similar T-DNA integration pattern is strain LMG201 Rif ${ }^{\mathrm{r}}$ (pMP90), which belongs to the same G8 group as C58. Very strikingly, for all analyzed Agrobacterium strains, a high inter-plant variability was observed during floral dip transformation of Arabidopsis Col-0, even when the same bacterial culture was used.

\section{MATERIALS AND METHODS}

\section{Agrobacterium strains.}

Agrobacterium strain C58C1 (Van Larebeke et al. 1974) was made resistant to erythromycin and chloramphenicol $\left(\mathrm{Ecm}^{\mathrm{r}}\right)$ by plating the bacteria on YEB medium supplemented with $50 \mu \mathrm{g}$ of erythromycin and $50 \mu \mathrm{g}$ of chloramphenicol per milliliter. C58C1 $\mathrm{Ecm}^{\mathrm{r}}$ (pMP90) was obtained from a biparental conjugation in which C58C1 Rif ${ }^{\mathrm{T}}$ (pMP90) (Koncz and Schell 1986) was the donor strain and $\mathrm{C} 58 \mathrm{C} 1 \mathrm{Ecm}^{\mathrm{r}}$ the acceptor strain.

From all eight wild-type LMG Agrobacterium strains (Table 1), a Rif ${ }^{\mathrm{r}}$ mutant was obtained by plating the Agrobacterium strains on YEB medium supplemented with $100 \mu \mathrm{g}$ of rifampicin per milliliter. Subsequently, several mutants were colony purified and a normally growing colony was selected. To introduce the nopaline pMP90 vir plasmid in the eight isolated Rif ${ }^{\mathrm{r}}$ Agrobacterium strains, the $\mathrm{C} 58 \mathrm{C} 1 \mathrm{Ecm}^{\mathrm{r}}$ (pMP90) strain was used in a second biparental conjugation as the donor strain. The Agrobacterium strains C58C1 Rif ${ }^{\mathrm{r}}$ (pGV2260) and LBA4404 were described before (Deblaere et al. 1985; Hoekema et al. 1983). Triparental conjugation between different Agrobacterium strains as acceptor, Escherichia coli HB101 (pRK2013) as helper, and E. coli MC1061 (pTJK136) as donor strain (Kapila et al. 1997) resulted in the transfer of the pTJK136 binary vector to the different mutant Agrobacterium strains (Ditta et al. 1980). The binary vector pTJK136 (Kapila et al. 1997) contains the NPTII gene driven by the promoter of the nopaline synthase (nos) gene conferring resistance to kanamycin and a GUS reporter gene under the control of the Cauliflower mosaic virus P35S promoter (Odell et al. 1985).

For the cotransformation experiments, the binary vector pAAVS1 was introduced via electroporation in the Agrobacterium strains LMG201 Rif ${ }^{\mathrm{r}}$ (pMP90), LMG62 Rif ${ }^{\mathrm{r}}$ (pMP90),
C58C1 Rif ${ }^{r}$ (pMP90), EHA101 (Hood et al. 1986), AGL1 (Lazo et al. 1991), LBA4404, and LBA4404 (virGN54D) (van der Fits et al. 2000). To produce the pAAVS1 vector, a compatible linker sequence was ligated into the SnaBI/HindIII site of pH610 (De Buck et al. 1998), containing the hygromycin phosphotransferase coding region whose expression was controlled by the $5^{\prime}$ and the $3^{\prime}$ regulatory regions of the nos gene.

\section{Floral dip transformation of Arabidopsis ecotypes \\ Col-0 and C24 and selection for transformants.}

Floral dip was modified from Clough and Bent (1998) and De Buck and associates (2012). After the Agrobacterium strains were freshly grown on solid selective medium, one colony of the Agrobacterium strain was inoculated in the morning in $1 \mathrm{ml}$ of Luria Bertani (LB) medium without antibiotics in a $50-\mathrm{ml} \mathrm{Fal-}$ con tube and was incubated for 7 to $8 \mathrm{~h}$ at $28^{\circ} \mathrm{C}$ in a rotary shaker at $230 \mathrm{rpm}$. In the evening, $10 \mathrm{ml}$ of LB medium was added, and the culture was incubated overnight. After the optical density at $600 \mathrm{~nm}\left(\mathrm{OD}_{600}\right)$ of the overnight-grown culture was measured (discussed below), $40 \mathrm{ml}$ of freshly made dipping solution $(10 \%(\mathrm{wt} / \mathrm{vol})$ of sucrose, $0.05 \%(\mathrm{vol} / \mathrm{vol})$ of Silwet L77 in double distilled $\mathrm{H}_{2} \mathrm{O}$ ) was added and mixed well by gentle inversion (not vortexed). To prepare the Agrobacterium suspensions for cotransformation, $5 \mathrm{ml}$ of each grown culture was added to $40 \mathrm{ml}$ of dipping solution. To grow the Arabidopsis plants, five to ten seeds were sown in Jiffy's, and plantlets were grown at $22^{\circ} \mathrm{C}$ (day) and $18^{\circ} \mathrm{C}$ (night) with a photoperiod of 12 $\mathrm{h}$ of light and $12 \mathrm{~h}$ of darkness and a relative humidity of 65 to $70 \%$. After two weeks, plantlets were transferred and one plant per Jiffy was inserted in $5.5-\mathrm{cm}$ pots. Plants were subirrigated for 15 min every 2 to 3 days and were given $0.2 \%$ npk-Wuxal super 8-8-6 every two weeks. To trigger the plants to produce multiple, synchronized secondary bolts, the inflorescences were cut off at the moment all the plants had formed primary bolts. Approximately two weeks later, in the morning around 10 a.m., the secondary flowering stems of 10 to $15 \mathrm{~cm}$ in length were dipped for $10 \mathrm{~s}$ by bending the inflorescences in the Falcon tube with the Agrobacterium suspension. Then, the plants were covered for $24 \mathrm{~h}$ with Saran Wrap. Afterwards, the plants were allowed to grow further in the greenhouse under normal conditions, $16 \mathrm{~h}$ of light and $8 \mathrm{~h}$ of darkness, $21^{\circ} \mathrm{C}$, and $55 \%$ relative humidity. Five weeks after floral dip, the plants were no longer watered and were transferred to a room at $25^{\circ} \mathrm{C}$ with a 20 -hlight and 4-h-dark photoperiod and low humidity. When the plants were completely dry (approximately eight weeks after dipping), T1 seeds were collected.

The density of Agrobacterium concentrations in the different dipping solutions was determined as an $\mathrm{OD}_{600}$ value of 1 corresponding to approximately $8 \times 10^{8}$ bacteria/ml. Floral dip transformation of the Arabidopsis Col-0 ecotype was performed in three biological repeats, using all bacterial strains except for C58C1 Rif ${ }^{\mathrm{r}}$ (pMP90, pTJK136) and C58C1 Rif ${ }^{\mathrm{r}}$ (pGV2260, pTJK136), in which four and two biological repeats were performed, respectively (Table 2). Floral dip transformation of $\mathrm{C} 24$ ecotype plants was carried out in two biological repeats (Table 2). In biological repeat c, the same bacterial cultures were used for floral dip of both the Arabidopsis Col-0 and C24 ecotypes (Table 2). In each biological repeat, five individual plants were dipped using the same Agrobacterium culture, the plants were allowed to set seeds, and the seeds were collected per individual plant. Arabidopsis seeds $(50 \mathrm{mg}$, $n=2,000$ ) harvested from each dipped plant were sown on kanamycin selective medium, and the number of kanamycinresistant Arabidopsis plants was scored for all dipped plants.

Floral dip cotransformation experiments were performed using a mixture of two bacterial strains prepared from individual bacterial cultures with equal OD values. Seeds $(25 \mathrm{mg}, n=$ 
$1,000)$ were sown on medium supplemented with either kanamycin or hygromycin $(20 \mathrm{mg} / \mathrm{liter})$ to select for transformants with the TJK136 and AAVS1 T-DNAs, respectively.

\section{Statistical analyses.}

Table 2. A negative binomial model was fit to the data with strain as the explanatory variable using the SAS proc genmod procedure (SAS/STAT software, vs. 9.3 of the SAS System for windows. (SAS Institute Inc., Cary, NC, U.S.A.). The correlation between the plants infected with the same floral dip solution was modeled with an exchangeable correlation structure. Score statistics for type 3 generalized estimating equations were computed for the strain effect. In the case of a significant strain effect $(P<0.05)$, post hoc Dunnett tests were performed using the C58C1 Rif ${ }^{\mathrm{T}}$ (pMP90, pTJK136) strain as control strain.

Table 3. To compare the number of kanamycin- and hygromycin-resistant transformants in de-cotransformation experiments, the nonparametric Wilcoxon signed rank test was performed on each Agrobacterium mixture using the SAS proc univariate procedure.

\section{Pathogenicity tests.}

Pathogenicity tests were performed on Nicotiana tabacum plants (SR1). Tobacco seeds were sterilized by soaking them for $2 \mathrm{~min}$ in $80 \%$ ethanol and, subsequently, for $8 \mathrm{~min}$ in $\mathrm{NaOCl} 6 \%$. The seeds were washed several times with sterile water and were sown on B5 medium supplemented with $1 \%$ sucrose. Three to four weeks later, one cotyledon of the tobacco plants was removed by cutting at the basal end of the leaf. Agrobacterium strains were then applied at the wound site. The in vitro pathogenicity test was performed in two biological repeats, and in each repeat, four tobacco plants per bacterial strain were infected. The wild-type Agrobacterium strain C58 and the derived cured strain C58C1 Rif ${ }^{\mathrm{r}}$ (pMP90, pTJK136) were used as controls.

\section{Segregation analysis, plant DNA preparation, and DNA gel blot analysis.}

To determine the T-DNA loci number, segregation analyses were performed on 31 transformants obtained from LMG201 Rif $^{\mathrm{r}}$ (pMP90, pTJK136) and 31 from C58C1 Rif ${ }^{\mathrm{r}}$ (pMP90, pTJK136) as described by De Buck and associates (2004).

DNA of transgenic Arabidopsis leaf material was prepared from 10 to $50 \mathrm{mg}$ of frozen plant leaves using the DNeasy plant mini kit (Westburg, Leusden, The Netherlands). NPTII and GUS probes were prepared according to De Buck and associates (1999). DNA was labeled and detected with the nonradioactive Roche labeling kit and Roche CDP star detection module (Roche Applied Sciences, Indianapolis, IN, U.S.A.). The filters were first hybridized with the GUS probe and, after stripping, were hybridized with the NPTII probe.

\section{ACKNOWLEDGMENTS}

The authors thank A. Jacobs for excellent technical help, V. Storme for help with statistical analysis of the data, and A. Bleys for help in preparing the manuscript. The research was funded by an FWO grant (project 3G021106).

\section{LITERATURE CITED}

Adam, L., Ellwood, S., Wilson, I., Saenz, G., Xiao, S., Oliver, R. P., Turner, J. G., and Somerville, S. 1999. Comparison of Erysiphe cichoracearum and E. cruciferarum and a survey of 360 Arabidopsis thaliana accessions for resistance to these two powdery mildew pathogens. Mol. Plant-Microbe Interact. 12:1031-1043.

Akama, K., Shiraishi, H., Ohta, S., Nakamura, K., Okada, K., and Shimura, Y. 1992. Efficient transformation of Arabidopsis thaliana: Comparison of the efficiencies with various organs, plant ecotypes and Agrobacterium strains. Plant Cell Rep. 12:7-11.

Aloni, R., and Ullrich, C. I. 2008. Biology of crown gall tumors. Pages 565-591 in: Agrobacterium: From Biology to Biotechnology, T. Tzfira and V. Citovsky, eds. Springer, New York.

Bechtold, N., Ellis, J., and Pelletier, G. 1993. In planta Agrobacterium mediated gene transfer by infiltration of adult Arabidopsis thaliana plants. C. R. Acad. Sci., Ser 3 316:1194-1199.

Bechtold, N., Jaudeau, B., Jolivet, S., Maba, B., Vezon, D., Voisin, R., and Pelletier, G. 2000. The maternal chromosome set is the target of the TDNA in the in planta transformation of Arabidopsis thaliana. Genetics 155:1875-1887.

Bechtold, N., Jolivet, S., Voisin, R., and Pelletier, G. 2003. The endosperm and the embryo of Arabidopsis thaliana are independently transformed through infiltration by Agrobacterium tumefaciens. Transgenic Res. 12:509-517.

Binns, A. N. 2008. A brief history of research on Agrobacterium tumefaciens: 1900-1980s. Pages 47-72 in: Agrobacterium: From Biology to Biotechnology, T. Tzfira and V. Citovsky, eds. Springer, New York.

Broothaerts, W., Mitchell, H. J., Weir, B., Kaines, S., Smith, L. M. A., Yang, W., Mayer, J. E., Roa-Rodriguez, C., and Jefferson, R. A. 2005. Gene transfer to plants by diverse species of bacteria. Nature 433:629-633.

Butaye, K. M. J., Goderis, I. J. W. M., Wouters, P. F. J., Pues, J. M.-T. G. Delauré, S. L., Broekaert, W. F., Depicker, A., Cammue, B. P. A., and De Bolle, M. F. C. 2004. Stable high-level transgene expression in Arabidopsis thaliana using gene silencing mutants and matrix attachment regions. Plant J. 39:440-449.

Cheng, M., Lowe, B. A., Spencer, T. M., Ye, X., and Armstrong, C. L. 2004. Factors influencing Agrobacterium-mediated transformation of monocotyledonous species. In Vitro Cell. Dev. Biol.-Plant 40:31-45.

Citovsky, V., Kozlovsky, S. V., Lacroix, B., Zaltsman, A., Dafny-Yelin, M., Vyas, S., Tovkach, A., and Tzfira, T. 2007. Biological systems of the host cell involved in Agrobacterium infection. Cell. Microbiol. 9:9-20.

Clough, S. J., and Bent, A. F. 1998. Floral dip: A simplified method for Agrobacterium-mediated transformation of Arabidopsis thaliana. Plant J. 16:735-743.

Costechareyre, D., Bertolla, F., and Nesme, X. 2009. Homologous recombination in Agrobacterium: Potential implications for the genomic species concept in bacteria. Mol. Biol. Evol. 26:167-176.

Dafny-Yelin, M., Levy, A., and Tzfira, T. 2008. The ongoing saga of Agrobacterium-host interactions. Trends Plant Sci. 13:102-105.

De Buck, S., and Depicker, A. 2004. Gene expression and level of expression. Pages 331-345 in: Handbook of Plant Biotechnology, P. Christou and H. Klee, eds. John Wiley \& Sons, Ltd., New York.

De Buck, S., Jacobs, A., Van Montagu, M., and Depicker, A. 1998. Agrobacterium tumefaciens transformation and cotransformation frequencies of Arabidopsis thaliana root explants and tobacco protoplasts. Mol. Plant-Microbe Interact. 11:449-457.

De Buck, S., Jacobs, A., Van Montagu, M., and Depicker, A. 1999. The DNA sequences of T-DNA junctions suggest that complex T-DNA loci are formed by a recombination process resembling T-DNA integration. Plant J. 20:295-304.

De Buck, S., Windels, P., De Loose, M., and Depicker, A. 2004. Singlecopy T-DNAs integrated at different positions in the Arabidopsis genome display uniform and comparable $\beta$-glucuronidase accumulation levels. Cell. Mol. Life Sci. 61:2632-2645.

De Buck, S., Podevin, N., Nolf, J., Jacobs, A., and Depicker, A. 2009. The T-DNA integration pattern in Arabidopsis transformants is highly determined by the transformed target cell. Plant J. 60:134-145.

De Buck, S., Virdi, V., De Meyer, T., De Wilde, K., Piron, R., Nolf, J., Van Lerberge, E., De Paepe, A., and Depicker, A. 2012. Production of camel-like antibodies in plants. Pages 305-324 in: Single Domain Antibodies: Methods and Protocols, S. Muyldermans and D. Saerens, eds. Humana Press, New York.

De Ley, J. 1972. Agrobacterium: Intrageneric relationships and evolution. Pages 251-259 in: Proceedings of the Third International Conference on Plant Pathogenic Bacteria, H. P. Maas Geesteranus, ed. Centre for Agricultural Publishing and Documentation, Wageningen, The Netherlands.

De Ley, J. 1974. Phylogeny of the prokaryotes. Taxon 23:291-300.

Deblaere, R., Bytebier, B., De Greve, H., Deboeck, F., Schell, J., Van Montagu, M., and Leemans, J. 1985. Efficient octopine Ti plasmidderived vectors for Agrobacterium-mediated gene transfer to plants. Nucleic Acids Res. 13:4777-4788.

Depicker, A., De Wilde, M., De Vos, G., De Vos, R., Van Montagu, M., and Schell, J. 1980. Molecular cloning of overlapping segments of the nopaline Ti-plasmid pTiC58 as a means to restriction endonuclease mapping. Plasmid 3:193-211.

Desfeux, C., Clough, S. J., and Bent, A. F. 2000. Female reproductive tissues are the primary target of Agrobacterium-mediated transformation by the Arabidopsis floral-dip method. Plant Physiol. 123:895-904. 
Dillen, W., De Clercq, J., Kapila, J., Zambre, M., Van Montagu, M., and Angenon, G. 1997. The effect of temperature on Agrobacterium tumefaciens-mediated gene transfer to plants. Plant J. 12:1459-1463.

Ditta, G., Stanfield, S., Corbin, D., and Helinski, D. R. 1980. Broad host range DNA cloning system for Gram-negative bacteria: Construction of a gene bank of Rhizobium meliloti. Proc. Natl. Acad. Sci. U.S.A. 77:7347-7351.

Gelvin, S. B. 2010. Plant proteins involved in Agrobacterium-mediated genetic transformation. Annu. Rev. Phytopathol. 48:45-68.

Gelvin, S. B. 2012. Traversing the cell: Agrobacterium T-DNA's journey to the host genome. Front. Plant Sci. 3:52.

Goodner, B., Hinkle, G., Gattung, S., Miller, N., Blanchard, M., Qurollo, B., Goldman, B. S., Cao, Y., Askenazi, M., Halling, C., Mullin, L., Houmiel, K., Gordon, J., Vaudin, M., Iartchouk, O., Epp, A., Liu, F., Wollam, C., Allinger, M., Doughty, D., Scott, C., Lappas, C., Markelz, B., Flanagan, C., Crowell, C., Gurson, J., Lomo, C., Sear, C., Strub, G., Cielo, C., and Slater, S. 2001. Genome sequence of the plant pathogen and biotechnology agent Agrobacterium tumefaciens C58. Science 294:2323-2328

Hoekema, A., Hirsch, P. R., Hooykaas, P. J. J., and Schilperoort, R. A 1983. A binary plant vector strategy based on separation of Vir and Tregion of the Agrobacterium tumefaciens Ti-plasmid. Nature 303:179180.

Hood, E. E., Helmer, G. L., Fraley, R. T., and Chilton, M.-D. 1986. The hypervirulence of Agrobacterium tumefaciens A281 is encoded in a region of pTiBo542 outside of T-DNA. J. Bacteriol. 168:1291-1301.

Kapila, J., De Rycke, R., Van Montagu, M., and Angenon, G. 1997. An Agrobacterium-mediated transient gene expression system for intact leaves. Plant Sci. 122:101-108.

Katavic, V., Haughn, G. W., Reed, D., Martin, M., and Kunst, L. 1994. In planta transformation of Arabidopsis thaliana. Mol. Gen. Genet. 245:363-370

Kersters, K., and De Ley, J. 1984. Genus III. Agrobacterium Conn 1942, $359^{\mathrm{AL}}$. Pages 244-254 in: Bergey's Manual of Systematic Bacteriology, N. R. Krieg and J. G. Holt, eds. Williams \& Wilkins, Baltimore, MD, U.S.A.

Koncz, C., and Schell, J. 1986. The promoter of TL-DNA gene 5 controls the tissue-specific expression of chimaeric genes carried by a novel type of Agrobacterium binary vector. Mol. Gen. Genet. 204:383-396.

Lazo, G. R., Stein, P. A., and Ludwig, R. A. 1991. A DNA transformationcompetent Arabidopsis genomic library in Agrobacterium. Biotechnology 9:963-967.

Leigh, J. A., and Coplin, D. L. 1992. Exopolysaccharides in plant-bacterial interactions. Annu. Rev. Microbiol. 46:307-346.

McCullen, C. A., and Binns, A. N. 2006. Agrobacterium tumefaciens and plant cell interactions and activities required for interkingdom macromolecular transfer. Annu. Rev. Cell Dev. Biol. 22:101-127.

Melchers, L. S., Maroney, M. J., den Dulk-Ras, A., Thompson, D. V., van Vuuren, H. A., Schilperoort, R. A., and Hooykaas, P. J. 1990. Octopine and nopaline strains of Agrobacterium tumefaciens differ in virulence: molecular characterization of the virF locus. Plant Mol. Biol. 14:249259.

Nair, G. R., Liu, Z., and Binns, A. N. 2003. Reexamining the role of the accessory plasmid pAtC58 in the virulence of Agrobacterium tumefaciens strain C58. Plant Physiol. 133:989-999.

Nam, J., Matthysse, A. G., and Gelvin, S. B. 1997. Differences in susceptibility of Arabidopsis ecotypes to crown gall disease may result from a deficiency in T-DNA integration. Plant Cell 9:317-333.

Odell, J. T., Nagy, F., and Chua, N.-H. 1985. Identification of DNA sequences required for activity of the cauliflower mosaic virus $35 \mathrm{~S}$ promoter. Nature 313:810-812

Oltmanns, H., Frame, B., Lee, L.-Y., Johnson, S., Li, B., Wang, K., and Gelvin, S. B. 2010. Generation of backbone-free, low transgene copy plants by launching T-DNA from the Agrobacterium chromosome. Plant Physiol. 152:1158-1166.

Opabode, J. T. 2006. Agrobacterium-mediated transformation of plants: Emerging factors that influence efficiency. Biotechnol. Mol. Biol. Rev. $1: 12-20$

Pitzschke, A., and Hirt, H. 2010. New insights into an old story: Agrobacterium-induced tumour formation in plants by plant transformation. EMBO (Eur. Mol. Biol. Organ.) J. 29:1021-1032.

Portier, P., Fischer-Le Saux, M., Mougel, C., Lerondelle, C., Chapulliot, D., Thioulouse, J., and Nesme, X. 2006. Identification of genomic species in Agrobacterium biovar 1 by AFLP genomic markers. Appl. Environ. Microbiol. 72:7123-7131

Sainsbury, F., Thuenemann, E. C., and Lomonossoff, G. P. 2009. pEAQ:
Versatile expression vectors for easy and quick transient expression of heterologous proteins in plants. Plant Biotechnol. J. 7:682-693.

Shen, W. H., Escudero, J., Schlappi, M., Ramos, C., Hohn, B., and Koukolikova-Nicola, Z. 1993. T-DNA transfer to maize cells: Histochemical investigation of $\beta$-glucuronidase activity in maize tissues. Proc. Natl. Acad. Sci. U.S.A. 90:1488-1492.

Slater, S. C., Goodner, B. W., Setubal, J. C., Goldman, B. S., Wood, D. W., and Nester, E. W. 2008. The Agrobacterium tumefaciens C58 genome. Pages 149-181 in: Agrobacterium: From Biology to Biotechnology, T. Tzfira and V. Citovsky, eds. Springer, New York.

Tadege, M., Sheldon, C. C., Helliwell, C. A., Upadhyaya, N. M., Dennis, E. S., and Peacock, W. J. 2003. Reciprocal control of flowering time by OsSOCl in transgenic Arabidopsis and by FLC in transgenic rice. Plant Biotechnol. J. 1:361-369.

Thomashow, M. F., Karlinsey, J. E., Marks, J. R., and Hurlbert, R. E. 1987. Identification of a new virulence locus in Agrobacterium tumefaciens that affects polysaccharide composition and plant cell attachment. J. Bacteriol. 169:3209-3216.

Truernit, E., and Haseloff, J. 2008. Arabidopsis thaliana outer ovule integument morphogenesis: Ectopic expression of KNAT1 reveals a compensation mechanism. BMC Plant Biol. 8:35.

Tzfira, T., and Citovsky, V. 2000. From host recognition to T-DNA integration: The function of bacterial and plant genes in the Agrobacteriumplant cell interaction. Mol. Plant Pathol. 1:201-212.

Tzfira, T., and Citovsky, V. 2006. Agrobacterium-mediated genetic transformation of plants: Biology and biotechnology. Curr. Opin. Biotechnol. 17:147-154.

Tzfira, T., Li, J., Lacroix, B., and Citovsky, V. 2004. Agrobacterium TDNA integration: Molecules and models. Trends Genet. 20:375-383.

Valvekens, D., Van Montagu, M., and Van Lijsebettens, M. 1988. Agrobacterium tumefaciens-mediated transformation of Arabidopsis thaliana root explants by using kanamycin selection. Proc. Natl. Acad. Sci. U.S.A. 85:5536-5540.

van der Fits, L., Deakin, E. A., Hoge, J. H. C., and Memelink, J. 2000. The ternary transformation system: Constitutive virG on a compatible plasmid dramatically increases Agrobacterium-mediated plant transformation. Plant Mol. Biol. 43:495-502.

Van Larebeke, N., Engler, G., Holsters, M., Van den Elsacker, S., Zaenen, I., Schilperoort, R. A., and Schell, J. 1974. Large plasmid in Agrobacterium tumefaciens essential for crown gall-inducing ability. Nature 252:169-170

Wiktorek-Smagur, A., Hnatuszko-Konka, K., and Kononowicz, A. K. 2009. Flower bud dipping or vacuum infiltration-Two methods of Arabidopsis thaliana transformation. Russ. J. Plant Physiol. 56:560568.

Wood, D. W., Setubal, J. C., Kaul, R., Monks, D. E., Kitajima, J. P., Okura, V. K., Zhou, Y., Chen, L., Wood, G. E., Almeida, N. F., Jr., Woo, L., Chen, Y., Paulsen, I. T., Eisen, J. A., Karp, P. D., Bovee, D., Sr., Chapman, P., Clendenning, J., Deatherage, G., Gillet, W., Grant, C., Kutyavin, T., Levy, R., Li, M. J., McClelland, E., Palmieri, A., Raymond, C., Rouse, G., Saenphimmachak, C., Wu, Z., Romero, P., Gordon, D., Zhang, S., Yoo, H., Tao, Y., Biddle, P., Jung, M., Krespan, W., Perry, M., Gordon-Kamm, B., Liao, L., Kim, S., Hendrick, C., Zhao, Z. Y., Dolan, M., Chumley, F., Tingey, S. V., Tomb, J. F., Gordon, M. P., Olson, M. V., and Nester, E. W. 2001. The genome of the natural genetic engineer Agrobacterium tumefaciens C58. Science 294:2317-2323.

Ye, G.-N., Stone, D., Pang, S.-Z., Creely, W., Gonzalez, K., and Hinchee, M. 1999. Arabidopsis ovule is the target for Agrobacterium in planta vacuum infiltration transformation. Plant J. 19:249-257.

Zheng, M. S., Takahashi, H., Miyazaki, A., Yamaguchi, K., and Kusano, T. 2005. Identification of the cis-acting elements in Arabidopsis thaliana NHL10 promoter responsible for leaf senescence, the hypersensitive response against Cucumber mosaic virus infection, and spermine treatment. Plant Sci. 168:415-422.

Zorreguieta, A., Geremia, R. A., Cavaignac, S., Cangelosi, G. A., Nester, E. W., and Ugalde, R. A. 1988. Identification of the product of an Agrobacterium tumefaciens chromosomal virulence gene. Mol. PlantMicrobe Interact. 1:121-127.

\section{AUTHOR-RECOMMENDED INTERNET RESOURCES}

Belgian Co-Ordinated Collections Of Micro-Organisms (BCCM) database: bccm.belspo.be/index.php

Roche Applied Sciences website: www.roche-applied-science.com/index.jsp 